\title{
25. THERMOGENIC AND BACTERIAL HYDROCARBON GASES (FREE AND SORBED) IN MIDDLE VALLEY, JUAN DE FUCA RIDGE, LEG 1391
}

\author{
Michael J. Whiticar, ${ }^{2}$ Eckhard Faber, ${ }^{3}$ Jean K. Whelan, ${ }^{4}$ and Bernd R.T. Simoneit ${ }^{5}$
}

\begin{abstract}
The sorbed gases at all four Ocean Drilling Program Leg 139 sites $(855,856,857$, and 858$)$ showed the unmistakable presence of thermogenic hydrocarbons. No indication of abiogenic gas was found. The evidence for the thermogenic hydrocarbons includes elevated contents of higher hydrocarbons (i.e., $\mathrm{C}_{1} /\left[\mathrm{C}_{2}+\mathrm{C}_{3}\right]$ ca. $2-20$ ), $\delta^{13} \mathrm{C}_{\mathrm{CH}_{4}}$ between $-30 \%$ and $-45 \%$ (PDB), $\delta^{13} \mathrm{C}_{\mathrm{C}_{2} \mathrm{H}_{6}}$ between $-18.7 \%$ and $-26.1 \%$, and $\delta^{13} \mathrm{C}_{\mathrm{C}_{3} \mathrm{H}_{8}}$ from $-20.5 \%$ to $-25.1 \%$. The carbon isotope ratios of $\mathrm{C}_{2}$ and $\mathrm{C}_{3}$ indicate that the organic matter that generated these hydrocarbons is mature to overmature ( $1.8 \%$ to $4 \%$ Ro equivalent) reflecting the range in higher heat flow in the region. Considering the geologic setting, it is highly probable that the thermogenic gas was formed by hydrothermal processes. The presence of considerable amounts of ethene and propene (up to 7.1 hydrocarbon percent [h.c.\%]) along with the accelerated maturation of organic matter support this conclusion. Some of the sorbed gases, especially at Sites 857 and 858 , have a possible bacterial gas component admixed with the thermogenic, as is also seen in the free gases.

The free gases are generally distinct from the sorbed gases and have $\mathrm{C}_{1} /\left(\mathrm{C}_{2}+\mathrm{C}_{3}\right)$ ratios up to 200 and $\delta^{13} \mathrm{C}_{\mathrm{CH}_{4}}$ as light as $-56.1 \%$. The bacterial hydrocarbons in the free gas are most prominent at depths where bacterial sulfate reduction has removed most or all of the dissolved sulfate.

It is uncertain from the geochemical information whether or not the hydrothermal gases are autothonous or have migrated into the sediments vertically or laterally. However, the general increase in hydrocarbon concentration with depth could indicate a limited upward diffusion or advection which is consistent with the heat and fluid flow information for these holes.
\end{abstract}

\section{INTRODUCTION}

Fluid flow associated with hydrothermal circulation at the sedimented Middle Valley rift was one of the primary objectives of study during drilling at the Juan de Fuca Ridge, off Vancouver Island (Davis, Mottl, Fisher, et al., 1992). The four sites occupied during Ocean Drilling Program (ODP) Leg 139 had expressly different hydrologic conditions. Site 855 encountered a fault-controlled fluid recharge zone at the eastern edge of Middle Valley, expected to be influenced little by hydrothermal processes. Site 856 is at the location of an inactive metal sulfide accumulation created by previous hydrothermal activity. In contrast, Sites 857 and 858 are located in areas of active hydrothermalism. The former penetrated a zone of high temperature fluids, while the holes of Site 858 were spudded at an active hydrothermal vent field. Geological, geophysical, and geochemical details of Leg 139 are reported by Davis, Mottl, Fisher, et al. (1992).

\section{BACKGROUND ORGANIC GEOCHEMISTRY}

The following is a brief capsule of the shipboard organic geochemical results, only as they pertain to the free/sorbed gas investigation. The reader is directed to the more detailed accounting of shipboard results by Davis, Mottl, Fisher, et al. (1992) and elsewhere in this volume.

\footnotetext{
'Mottl, M.J., Davis, E.E., Fisher, A.T., and Slack, J.F. (Eds.), 1994. Proc. ODP. Sci. Results, 139: College Station, TX (Ocean Drilling Program).

${ }^{2}$ School of Earth and Ocean Sciences (SEOS), University of Victoria, Victoria, B.C., V8W 2 Y 2, Canada.

${ }^{3}$ Federal Institute for Geosciences and Natural Resources (BGR), Stilleweg 2, 3000 Hannover 51, FRG.

${ }^{4}$ Dept. of Chemistry, Woods Hole Oceanographic Institute (WHOI), Woods Hole, MA 02543, U.S.A.

${ }^{5}$ College of Oceanography, Oregon State University (OSU), Corvallis, OR 973315503, U.S.A.
}

\section{Site 855 (ca. $48^{\circ} 26.5^{\prime} \mathrm{N}, 128^{\circ} 38.3 \mathrm{~W}, 2444 \mathrm{~m}$ water depth)}

Sulfate is present in all the holes at Site 855. Minor sulfate reduction is noted in the uppermost $20 \mathrm{mbsf}$, but remained above $21 \mathrm{mM}$ This reflects the relatively organic poor nature (generally $<0.6 \%$ total organic carbon $[\mathrm{TOC}]$ ) of the hemipelagic turbidite sediments at this location. As a consequence, there is no methanogenic activity recorded at Site 855 . Methane in the headspace ranges only between 2-6 parts per million by volume (ppmv) and no higher hydrocarbons or sulfide were measured.

\section{Site 856 (ca. $48^{\circ} 26.0^{\prime} \mathrm{N}, 128^{\circ} 40.8 \mathrm{~W}, 2420 \mathrm{~m}$ water depth)}

As at Site 855, sulfate reduction was limited and in fact a slight enrichment in pore-fluid sulfate over seawater sulfate ( $31 \mathrm{mM}$ vs. 28 $\mathrm{mM}$ ) was recorded around $50 \mathrm{mbsf}$. With the exception of a few excursions to $0.8 \%$, the TOC remained less than $0.4 \%$ at Site 856 . Similar to measurements at Site 855, methane in the headspace was between 2-7 ppmv and again no higher hydrocarbons or sulfide were measured.

\section{Site 857 (ca. $48^{\circ} 26.5^{\prime} \mathrm{N}, 128^{\circ} 42.7 \mathrm{~W}, 2420$ m water depth)}

Sulfate concentrations dropped rapidly in the uppermost $200 \mathrm{mbsf}$ from seawater values to less than $5 \mathrm{mM}$. Below this, dissolved sulfate gradually decreased to a minimum of $3 \mathrm{mM}$, significantly above the ca. $0.5 \mathrm{mM} \mathrm{SO}_{4}$ threshold generally thought necessary for the accumulation of methane formed by bacterial methanogenesis.

In Hole $857 \mathrm{~A}$, headspace methane was typically low, i.e., $<10$ ppmv, down to $110 \mathrm{mbsf}$. A similar distribution was recorded down to $24 \mathrm{mbsf}$ and to about $100 \mathrm{mbsf}$ in Holes $857 \mathrm{~B}$ and $857 \mathrm{C}$, respectively. In these near-surface sediments, there was no appearance of higher hydrocarbons or reduced sulfur gases, analogous to Sites 855 and 857 . However, at Hole $857 \mathrm{C}$, below $120 \mathrm{mbsf}$ and especially below $200 \mathrm{mbsf}$, the gas character changed dramatically. Headspace methane increased to a maximum of $80,000 \mathrm{ppmv}$ at $300 \mathrm{mbsf}$, then remained constant down to $400 \mathrm{mbsf}$. A slight decrease in headspace methane was recorded below $400 \mathrm{mbsf}$ down to total depth (TD) at $558 \mathrm{mbsf}$. Accom- 
Table 1. Summary of total organic carbon (TOC) and dissolved sulfate ( $\left.\mathrm{SO}_{4}=\right)$ at Sites $\mathbf{8 5 5}$, 856, 857, and 858 (after Davis, Mottl, Fisher et al., 1992).

\begin{tabular}{|c|c|c|c|c|}
\hline $\begin{array}{l}\text { Site/ } \\
\text { Hole }\end{array}$ & $\begin{array}{l}\text { Max. T. } \\
\left({ }^{\circ} \mathrm{C}\right)\end{array}$ & $\begin{array}{l}\text { T. Grad. } \\
\left({ }^{\circ} \mathrm{C} / \mathrm{m}\right)\end{array}$ & $\begin{array}{c}\text { Dissolved } \mathrm{SO}_{4}=(\mathrm{mM}) \\
(\mathrm{sw}=\text { bottom water }=27.95 \mathrm{mM})\end{array}$ & $\begin{array}{l}\text { TOC } \\
(w t \%)\end{array}$ \\
\hline 855 & ca. 26 & 0.328 & $\begin{array}{l}\text { Generally }>21 \mathrm{mM} \text {, } \\
0 \text { mbsf }=28 ; 15 \mathrm{mbsf}=21 \mathrm{mM} \text { min.; } \\
\text { increases with depth to } 28 \mathrm{mM}\end{array}$ & $\begin{array}{c}\text { Generally }<0.6 \\
0 \text { mbsf }=0.0\end{array}$ \\
\hline 856 & ca. 70 & 0.5 & $\begin{array}{l}\text { Generally }>27 \mathrm{mM} \text {; slight increase with } \\
\text { depth; max. ca. } 50 \mathrm{mbsf}=31 \mathrm{mM}\end{array}$ & $\begin{array}{c}\text { Generally }<0.6 \text { local } \\
\max .=0.8\end{array}$ \\
\hline 857 & $\begin{array}{l}\mathrm{C}=135 \\
\mathrm{D}=230\end{array}$ & $\begin{array}{l}0.71 \\
1.3\end{array}$ & $\begin{array}{l}\text { Decreases regularly with depth from } 28 \mathrm{mM} \\
\text { to near-zero at } 200 \text {; persists at }\end{array}$ & Generally $<0.6$ \\
\hline $858 \mathrm{~A}$ & ca. 110 & 1.4 & $\begin{array}{l}28 \mathrm{mM} \text { to } 5 \mathrm{mM} \text { at } 100 \mathrm{mbsf} \text {; up to sw at } \\
180 \mathrm{mbsf} ;>200 \mathrm{mbsf} \text { sharp drop to }<5 \mathrm{mM}\end{array}$ & Generally $<0.4$ \\
\hline $858 \mathrm{~B}$ & $>200$ & 10 & $\begin{array}{l}0 \mathrm{mbsf}=28 \mathrm{mM} \text {; rapid decrease with } \\
\text { depth; } 26 \mathrm{mbsf}=0 \mathrm{mM} \text { (TD) }\end{array}$ & $\begin{array}{l}0.8 \text { at surface; down } \\
\text { to } 0.0 \text { at } 25 \text { mbsf }\end{array}$ \\
\hline $858 \mathrm{C}$ & ca. 125 & 3.0 & $\begin{array}{l}0-42 \text { mbsf ca. sw }(28 \mathrm{mM})>42 \mathrm{mbsf} \\
\text { gradual decrease to } 3 \mathrm{mM} \text { by } 84 \mathrm{~m} \text { (TD) }\end{array}$ & $\begin{array}{l}\text { Generally }<0.5 \\
\text { except } 0 \mathrm{msfb}=1.0\end{array}$ \\
\hline 858D & ca. 220 & 10 & Variable between $0-8$, but generally low & $\begin{array}{l}>5 \text { mbsf }=0.8 \text { to } 0.4 \\
>5 \text { mbsf decrease } \\
\text { to } 0.4 \text { to }<0.2\end{array}$ \\
\hline $858 \mathrm{~F}$ & ca. 260 & 0.5 & Between 4-7 mM & Generally $<0.2$ \\
\hline
\end{tabular}

Notes: At Site 858 , Hole $858 \mathrm{C}$ was the coolest, followed by $858 \mathrm{~A}$; Hole $858 \mathrm{~B}$ had the highest temperature gradient, while $858 \mathrm{~F}$ was the hottest hole. TD $=$ total depth.

panying the increase in methane below 200 mbsf was the appearance and similar increase in both headspace ethane and propane.

\section{Site 858 (ca. $48^{\circ} 27.4^{\prime} \mathrm{N}, 128^{\circ} 42.6 \mathrm{~W}, 2426 \mathrm{~m}$ water depth)}

Sulfate removal was more severe and close to exhaustion in the deeper sections of Site 858. Complete sulfate depletion was recorded for Samples 139-858B-5H-2, 143-150 cm, and 858B-5H-3, 140-150 $\mathrm{cm}$, at 26.87 and $28.35 \mathrm{mbsf}$, respectively. As at the other sites, TOC was generally $<0.4 \%$. There is a strong suggestion (Davis, Mottl, Fisher, et al., 1992, Site 858, Fluid Geochemistry Section) that the sulfate is removed inorganically by gypsum and anhydrite formation rather than by bacterial sulfate reduction.

In the upper sections ( $35 \mathrm{mbsf}$ ) of the cooler Holes $858 \mathrm{~A}$ and $858 \mathrm{C}$, the methane and higher hydrocarbon concentrations were similar to the previous three sites. But deeper in these holes, and throughout Holes $858 \mathrm{~B}, \mathrm{D}$, and F, headspace methane contents were high, up to 84,000 ppmv. Ethane, propane, and butane are also present in amounts up to 853 ppmv (Sample 139-858B-5H-CC, at 31.5 mbsf).

\section{Overview of Geochemical Conditions Operative at Leg 139 Sites}

Table 1 provides an overview of the temperature, heat flow, sulfate, and organic carbon variations encountered at Sites 855, 856, 857, and 858 of Leg 139. In general, Sites 855 and 856 are more quiescent, whereas Sites 857 and 858 have more extreme heat regimes.

\section{ANALYSIS OF FREE AND SORBED HYDROCARBONS}

\section{Gas Type Terminology}

1. Headspace Gases: 5 to $10 \mathrm{~cm}^{3}$ plugs of sediment are immediately taken from cores on the "sampling catwalk" and sealed into septum-capped glass vials. Following heating to $60^{\circ} \mathrm{C}$ for $45 \mathrm{~min}$, the gases in the headspace of the vial were analyzed by gas chromatography (see Davis, Mottl, Fisher, et al., 1992, Explanatory Notes chapter).

2. Expansion Void Gases (EVG, aka: Vacutainer® Gases): gas samples taken on the "sampling catwalk" through the core liner, where gas pockets have formed by expansion of the gases in sediments. Samples are collected and stored in pre-evacuated glass tubes with septa, i.e., Vacutainers ${ }^{\circledR}$ (see Davis, Mottl, Fisher, et al., 1992, Explanatory Notes chapter). These were the samples made available for carbon isotope measurements of the free gas hydrocarbons at the shorebased School of Earth and Ocean Sciences (SEOS), Victoria laboratory.

3. Free Gases: headspace gases and/or EVG-interstitial or loosely bound gases contained within the sediment.

4. Sorbed gases: shorebased acid/vacuum extraction of bound gases in sediment following removal of loosely bound gas (Free Gas); according to the BGR, Hannover method (e.g., Faber and Stahl, 1984).

\section{Analytical Details}

\section{Free or Headspace Gases}

Free or headspace gases were collected on board as sediment plugs sealed into septum vials, or as void gases (core liner gas pockets) in pre-evacuated Vacutainers ${ }^{\circledR}$. These gases were analyzed routinely during Leg 139 by conventional analytical gas chromatography (GC). For analytical details, see Davis, Mottl, Fisher, et al. (1992), Explanatory Notes chapter. The results of these analyses are reported in the respective site chapters of Davis, Mottl, Fisher, et al. (1992). The carbon isotope ratios of the hydrocarbons were determined for selected EVG gas samples from Leg 139. The measurements were made at SEOS using the new on-line combustion technique of Gas Chromatograph-Combustion-Isotope Ratio Mass Spectrometry (GCC-IRMS) (Whiticar and Cederberg, in press). Because only small volumes of gas are required by the GC-C-IRMS $\left(<100\right.$ pmole $\left.\mathrm{CO}_{2}\right)$, the carbon isotope ratios reported are averaged data obtained from several measurements made on each gas sample. 
Table 2. Sorbed gas data from Leg 139.

\begin{tabular}{|c|c|c|c|c|c|c|c|c|c|c|c|}
\hline \multirow{2}{*}{$\begin{array}{c}\text { Sample ID } \\
\text { (hole/core/section) }\end{array}$} & \multirow{2}{*}{$\begin{array}{l}\text { Depth } \\
\text { (mbsf) }\end{array}$} & \multicolumn{5}{|c|}{ Composition (\% h.c. by vol) } & \multirow{2}{*}{$\begin{array}{l}\text { Yield } \\
\mathrm{CH}_{4}\end{array}$} & \multirow{2}{*}{$\delta^{13} \mathrm{C}_{1}$} & \multirow{2}{*}{$\frac{\delta^{13} \mathrm{C}_{2}}{(\% \text { PDB })}$} & \multirow[t]{2}{*}{$\delta^{13} \mathrm{C}_{3}$} & \multirow{2}{*}{$\begin{array}{c}\mathrm{C}_{1} / \\
\left.\mathrm{C}_{2}+\mathrm{C}_{3}\right)\end{array}$} \\
\hline & & $\mathrm{CH}_{4}$ & $\mathrm{C}_{2} \mathrm{H}_{4}$ & $\mathrm{C}_{2} \mathrm{H}_{6}$ & $\mathrm{C}_{3} \mathrm{H}_{6}$ & $\mathrm{C}_{3} \mathrm{H}_{8}$ & & & & & \\
\hline $855 \mathrm{~A}-4 \mathrm{R}-2$ & 28.87 & 49.0 & 2.2 & 6.8 & 3.7 & 7.7 & 223 & -44.6 & -24.0 & & 3 \\
\hline $855 C-1 R-4$ & 5.91 & 48.7 & 2.1 & 5.5 & 3.2 & 6.7 & 70 & -37.9 & & & 4 \\
\hline $855 \mathrm{C}-4 \mathrm{R}-3$ & 31.47 & 71.8 & 1.9 & 5.8 & 1.3 & 4.8 & 142 & -39.9 & -24.5 & & 7 \\
\hline $855 \mathrm{C}-10 \mathrm{R}-3$ & 89.27 & 90.8 & 0.0 & 3.5 & 0.0 & 2.1 & 119 & -41.4 & & & 16 \\
\hline $856 \mathrm{~A}-2 \mathrm{H}-1$ & 4.07 & 71.0 & 2.7 & 5.7 & 2.6 & 4.6 & 93 & -36.8 & & & 7 \\
\hline $856 \mathrm{~A}-6 \mathrm{H}-5$ & 48.07 & 78.3 & 0.5 & 10.1 & 0.0 & 4.4 & 234 & -36.3 & -22.3 & & 5 \\
\hline $856 \mathrm{~A}-13 \mathrm{H}-1$ & 106.67 & 98.1 & 0.0 & 0.5 & 0.0 & 0.2 & 470 & -34.2 & & & 140 \\
\hline $856 \mathrm{~B}-2 \mathrm{H}-2$ & 4.67 & 86.7 & 0.0 & 3.3 & 0.0 & 2.3 & 97 & -31.0 & & & 15 \\
\hline $856 \mathrm{~B}-10 \mathrm{X}-1$ & 72.17 & 85.3 & 0.0 & 3.4 & 0.0 & 2.5 & 40 & -30.2 & & & 14 \\
\hline $857 \mathrm{C}-3 \mathrm{R}-2$ & 69.37 & 91.2 & 0.0 & 3.5 & 0.0 & 1.8 & 223 & -36.1 & -22.9 & & 17 \\
\hline $857 C-15 R-3$ & 176.87 & 89.6 & 0.0 & 2.5 & 0.0 & 1.9 & 116 & -54.9 & & & 21 \\
\hline $857 \mathrm{C}-21 \mathrm{R}-2$ & 233.42 & 69.4 & 0.0 & 6.9 & 0.0 & 5.9 & 108 & -45.4 & & & 5 \\
\hline $857 \mathrm{C}-27 \mathrm{R}-1$ & 285.42 & 65.8 & 0.0 & 17.7 & 0.0 & 10.2 & 753 & -47.5 & -25.8 & -25.0 & 2 \\
\hline $857 \mathrm{C}-30 \mathrm{R}-\mathrm{CC}$ & 313.10 & 44.9 & 2.8 & 11.8 & 4.2 & 10.6 & 1063 & -44.2 & -25.6 & -24.9 & 2 \\
\hline $857 \mathrm{C}-46 \mathrm{R}-1$ & 400.47 & 77.2 & 1.0 & 9.1 & 1.2 & 3.5 & 1149 & -46.4 & -23.8 & & 6 \\
\hline $857 \mathrm{C}-49 \mathrm{R}-1$ & 415.02 & 80.5 & 0.7 & 8.8 & 0.8 & 3.8 & 689 & -34.1 & -23.0 & & 6 \\
\hline $857 \mathrm{C}-52 \mathrm{R}-2$ & 430.12 & 79.8 & 0.5 & 11.6 & 0.6 & 3.2 & 933 & -40.9 & -22.2 & -22.5 & 5 \\
\hline $858 \mathrm{~A}-2 \mathrm{H}-2$ & 5.31 & 65.2 & 2.5 & 7.0 & 2.6 & 6.6 & 185 & -38.8 & -25.5 & & 5 \\
\hline $858 \mathrm{~A}-7 \mathrm{H}-2$ & 52.77 & 63.0 & 0.5 & 14.6 & 0.0 & 8.3 & 330 & -39.8 & -26.1 & -25.1 & 3 \\
\hline $858 \mathrm{~A}-20 \mathrm{X}-1$ & 160.37 & 83.8 & 0.9 & 4.6 & 0.8 & 3.0 & 352 & -49.2 & -19.2 & & 11 \\
\hline $858 \mathrm{~A}-27 \mathrm{X}-1$ & 226.60 & 95.2 & 0.3 & 1.1 & 0.3 & 0.9 & 839 & -45.0 & & & 48 \\
\hline $858 \mathrm{~B}-1 \mathrm{H}-2$ & 2.97 & 41.7 & 1.6 & 6.0 & 3.2 & 7.2 & 138 & -37.5 & & & 3 \\
\hline $858 \mathrm{~B}-5 \mathrm{H}-1$ & 23.90 & 71.2 & 0.0 & 15.6 & 0.0 & 11.2 & 1266 & -50.1 & -20.8 & -20.5 & 3 \\
\hline $858 \mathrm{C}-1 \mathrm{H}-2$ & 2.91 & 78.2 & 1.1 & 5.2 & 0.0 & 4.5 & 171 & -37.6 & -24.5 & & 8 \\
\hline $858 \mathrm{C}-12 \mathrm{X}-1$ & 24.95 & 92.8 & 0.0 & 1.9 & 0.0 & 0.9 & 308 & -37.0 & -25.2 & & 34 \\
\hline $858 \mathrm{C}-5 \mathrm{H}-4$ & 69.87 & 87.0 & 0.4 & 2.5 & 0.8 & 1.2 & 481 & -36.3 & -18.7 & & 24 \\
\hline $858 \mathrm{D}-2 \mathrm{H}-5$ & 16.67 & 65.5 & 0.0 & 7.8 & 0.0 & 8.5 & 60 & -42.4 & -21.4 & -23.1 & 4 \\
\hline $858 \mathrm{D}-6 \mathrm{X}-1$ & 29.84 & 45.6 & 7.1 & 8.9 & 0.0 & 10.3 & 35 & & & & 2 \\
\hline $858 \mathrm{~F} 08.18 .91$ & 0.00 & 70.9 & 0.8 & 15.2 & 0.0 & 6.7 & & & & & 3 \\
\hline
\end{tabular}

Notes: Percent hydrocarbons (\% h.c.) may add up to $<100$ due to contributions of $\mathrm{C}_{4+}$ (e.g., butane) not listed; yield $\mathrm{CH}_{4}$ is $\mathrm{ppb}$ by wet sediment wt.; $\delta^{13} \mathrm{C}$ relative to PDB standard, and $\mathrm{C}_{1} /\left(\mathrm{C}_{2}+\mathrm{C}_{3}\right)$ on a vol\% basis.

\section{Sorbed Gas}

Sediment samples were collected and frozen on board. In the laboratory, 200 to $300 \mathrm{~g}$ maximum were weighed into a vacuum/acid degassing apparatus (Faber and Stahl, 1984). The free gases were removed prior to this analysis by washing/sieving and pumping. Only the residual bound or sorbed gases were analyzed. The recovered sorbed gases were quantified by conventional analytical GC. Hydrocarbon concentrations are reported on a dry weight basis (e.g., yield $C_{1}$ $\mathrm{ppb}=\mathrm{gC}_{1} / 10^{9} \mathrm{~g}$ dry sediment). The compositional ratio $\mathrm{C}_{1} / \mathrm{C}_{2+}=\mathrm{C}_{1} /$ $\left(\mathrm{C}_{2}+\mathrm{C}_{2}:+\mathrm{C}_{3}+\mathrm{C}_{3}:+\mathrm{i}, \mathrm{n}-\mathrm{C}_{4}\right)$, is on a volume percent basis (vol\%), where $\mathrm{C}_{1}, \mathrm{C}_{2}, \mathrm{C}_{3}$, and $\mathrm{i}, \mathrm{n}-\mathrm{C}_{4}$ are $\mathrm{n}$-alkanes and $\mathrm{C}_{2}: \mathrm{C}_{3}$ : are ethene and propene, respectively.

In preparation for isotope measurements, the hydrocarbon gases were partitioned by $\mathrm{GC}$, then combusted over $\mathrm{CuO}\left(880^{\circ} \mathrm{C}\right)$ and the resultant $\mathrm{CO}_{2}$ and $\mathrm{H}_{2} \mathrm{O}$ collected. ${ }^{13} \mathrm{C} /{ }^{12} \mathrm{C}$ ratios of methane and in several cases ethane and propane were measured on an isotope ratio mass spectrometer. Insufficient combustion water was available from the hydrocarbons in the samples for $\mathrm{D} / \mathrm{H}\left({ }^{2} \mathrm{H} /{ }^{1} \mathrm{H}\right)$ ratio measurement.

Stable isotope data are determined as ratios, e.g., ${ }^{13} \mathrm{C} /{ }^{12} \mathrm{C}$, and are reported as the magnitude of excursion in per mil (\%) of the sample isotope ratio relative to a known standard isotope ratio. The usual $\delta$-notation generally used in the earth sciences is:

$$
\delta R_{x}=\left(\frac{R_{a} / R_{b}-\text { sample }}{R_{a} / R_{b}-\text { standard }}-1\right) \times 10^{3}
$$

where $\mathrm{R}_{\mathrm{a}} / \mathrm{R}_{\mathrm{b}}$ are the isotope ratios, e.g., ${ }^{13} \mathrm{C} /{ }^{12} \mathrm{C}$, referenced relative to the Peedee belemnite (PDB) standard. Overall precision of the carbon isotope measurements is better than $\pm 0.3 \%$ for both the conventional and GC-C-IRMS measurement techniques.

\section{RESULTS \\ Sorbed Gases}

Twenty-nine sediment samples were selected from the four sites $(855,856,857$, and 858) of Leg 139 for analysis of the sorbed gases (Table 2). Methane $\left(C_{1}\right)$, ethane $\left(C_{2}\right)$, and propane $\left(C_{3}\right)$ are present in all samples run. In addition, the olefins, ethene $\left(\mathrm{C}_{2}:\right)$, and propene $\left(\mathrm{C}_{3}\right.$ : $)$ are recorded in several samples.

Methane yields vary between 35 and $1266 \mathrm{ppb}$ (wt gas/wt sediment), with the highest values found in Holes $857 \mathrm{C}$ (1063 ppb, 1149 $\mathrm{ppb})$ and $858 \mathrm{~B}(1266 \mathrm{ppb})$, as listed in Table 2. Methane is the predominant hydrocarbon present, comprising $41.7 \mathrm{vol} \%$ to 98.1 vol\%. Ethane is generally the next most common hydrocarbon encountered $(0.48 \mathrm{vol} \%$ to $17.7 \mathrm{vol} \%)$ followed by propane $(0.22 \mathrm{vol} \%$ to $11.2 \mathrm{vol} \%)$, then the olefins $(0.0 \mathrm{vol} \%$ to $7.1 \mathrm{vol} \%)$. The molecular $C_{1} /\left(C_{2}+C_{3}\right)$ ratio varies from a low of 2 to a maximum of 140 .

Carbon isotope measurements could be made for the sorbed methane $\left(\delta^{13} \mathrm{C}_{\mathrm{CH}_{4}}\right)$ on all but two samples (Table 2$)$. The majority of these values range between $-30 \%$ and $-45 \%$, with the most extreme $\delta^{13} \mathrm{C}_{\mathrm{CH}_{4}}$ values being $-30.2 \%$ and $-54.9 \%$. Sufficient ethane and propane was present in many samples to allow $\delta^{13} \mathrm{C}_{\mathrm{C}_{2} \mathrm{H}_{6}}$ and $\delta^{13} \mathrm{C}_{\mathrm{c}_{3} \mathrm{H}_{8}}$ determinations, respectively. The former range between $-18.7 \%$ and $-26.1 \%$, while $\delta^{13} \mathrm{C}_{\mathrm{C}_{3} \mathrm{H}_{8}}$ varied from $-20.5 \%$ to $-25.1 \%$. Although measurements from the four sites are significantly different, considerable information is obtained by plotting them together, albeit with different symbols, as a function of sediment sampling depth (Fig. 1). The immediate observations made from Figure 1 are: (1) the yield of methane trends to higher values with depth; (2) the proportion of methane, relative to the other hydrocarbon gases present, increases to a maximum approaching $100 \%$ around 100 mbsf, then decreases with further depth; (3) ethane mirrors methane (i.e., decreases to $100 \mathrm{mbsf}$ and then increases; also seen as the variations of the $\mathrm{C} 1 /(\mathrm{C} 2+\mathrm{C} 3)$ ratio; and (4) there is no depth trend to the methane carbon isotope ratios. 
Table 3. Free gas concentrations and methane stable carbon isotope ratio from Leg 139.

\begin{tabular}{|c|c|c|c|c|c|c|c|c|}
\hline Sample ID & $\begin{array}{l}\text { Depth } \\
\text { (mbsf) }\end{array}$ & $\begin{array}{c}\text { Methane } \\
(\mathrm{ppm})\end{array}$ & $\begin{array}{c}\text { Ethane } \\
\text { (ppm) }\end{array}$ & $\begin{array}{c}\text { Propane } \\
\text { (ppm) }\end{array}$ & $\begin{array}{l}\text { Butane } \\
(\mathrm{ppm})\end{array}$ & $\begin{array}{c}\mathrm{CO}_{2} \\
(\mathrm{ppm})\end{array}$ & $\begin{array}{c}\mathrm{C} 1 / \\
\left(\mathrm{C}_{2}+\mathrm{C}_{3}\right)\end{array}$ & $\begin{array}{c}\delta^{13} \mathrm{C}_{\mathrm{CH}_{4}} \\
\left.(\% \infty)^{4}\right)\end{array}$ \\
\hline $857 \mathrm{C}-47 \mathrm{R}-1,135-150$ & 409 & 233,266 & 1626 & 51 & 0 & nd & 101.13 & -51.3 \\
\hline $\begin{array}{l}857 \mathrm{C}-62 \mathrm{R}-1,142-150 \\
(10000 \mathrm{psi})(64 \mathrm{R}-2)\end{array}$ & 529 & 8907 & 96 & 22 & 0 & 1033 & 75.48 & -49.7 \\
\hline $\begin{array}{l}857 \mathrm{C}-62 \mathrm{R}-1,142-150 \\
(25000 \mathrm{psi})(64 \mathrm{R}-2)\end{array}$ & 529 & 8907 & 96 & 22 & 0 & 1033 & 75.48 & -54.0 \\
\hline $858 \mathrm{~A}-29 \mathrm{X}-1,39-46$ & 256 & 35705 & 252 & 40 & 0 & 5466 & 122.28 & -54.5 \\
\hline $858 \mathrm{~A}-30 \mathrm{X}-1,90-102 \# 2$ & 265 & 40286 & 388 & 36 & 0 & 6164 & 95.01 & -54.5 \\
\hline $858 \mathrm{~A}-39 \mathrm{X}-\mathrm{CC}$ & 339 & 38096 & 288 & 27 & 0 & 1526 & 120.94 & -53.2 \\
\hline $858 \mathrm{~B}-5 \mathrm{H}-4,63$ & 29 & 136000 & 1167 & 410 & 0 & 5424 & 86.24 & -53.2 \\
\hline $858 \mathrm{~B}-5 \mathrm{H}-4,134$ & 29.7 & 1736 & 60 & 0 & 0 & 1312 & 28.93 & -52.7 \\
\hline $\begin{array}{l}858 \mathrm{~B}-9 \mathrm{X}-1,10-13 \\
856 \mathrm{D}-1 \mathrm{H}-6 \mathrm{~A} \text { (CS } 2)\end{array}$ & & & & & & & 80.00 & $\begin{array}{l}-52.2 \\
-52.4\end{array}$ \\
\hline $856 \mathrm{D}-1 \mathrm{H}-6 \mathrm{~A}(\mathrm{CS} 2)$ & 7.5 & 938 & 14 & 0 & 0 & 1199 & 67.00 & $\begin{array}{l}-52.4 \\
-52.1\end{array}$ \\
\hline $858 \mathrm{D}-1 \mathrm{H}-6 \mathrm{~B}(\mathrm{CS} 2)$ & & nd & 4142 & 47 & 0 & 7553 & 67.00 & -52.1 \\
\hline $858 \mathrm{D}-2 \mathrm{H}$ & 12.3 & 534 & 14 & 10 & 0 & 2197 & 22.25 & \\
\hline 868D-4H (1) & 22.8 & 1873 & 22 & 13 & 0 & ND & 53.51 & -55.0 \\
\hline $858 \mathrm{D}-4 \mathrm{H}(2)(\mathrm{CS} 2)$ & 22.8 & 2447 & 32 & 18 & 0 & ND & 48.94 & \\
\hline $858 \mathrm{~F}-1 \mathrm{~W}(1)$ & 1.5 & 523 & 19 & 18 & 0 & 3620 & 14.14 & -53.4 \\
\hline $858 \mathrm{~F}-1 \mathrm{~W}$ & 1.5 & 523 & 19 & 18 & 0 & 3620 & 14.14 & -56.1 \\
\hline (3) & 1.5 & 523 & 19 & 18 & 0 & 3620 & 14.14 & \\
\hline $858 \mathrm{~F}-9 \mathrm{R}-\mathrm{CC}$ & 104 & 9048 & 33 & 0 & 0 & ND & 274.18 & -53.6 \\
\hline $858 \mathrm{~F}-13 \mathrm{R}-1,0-3$ & 133 & nd & 0 & 0 & 0 & 0 & 250.00 & -54.1 \\
\hline $858 \mathrm{~F}-25 \mathrm{R}-1,2-8$ & 249 & 92098 & 352 & 10 & 0 & ND & 254.41 & -53.3 \\
\hline
\end{tabular}

Note: Methane, ethane, propane and butane are reported on a vol\% of total headspace (including air), $\delta^{13} \mathrm{C}$ relative to $\mathrm{PDB}$ standard, and $\mathrm{C}_{1} /\left(\mathrm{C}_{2}+\mathrm{C}_{3}\right)$ on a vol\% basis.

\section{Free Gases}

A detailed presentation and discussion of the headspace and Vacutainer( shipboard results is contained in Davis, Mottl, Fisher, et al. (1992). This discussion will provide an overview synthesis of these free gas data together with the sorbed gas data and present the corresponding carbon isotope data (Table 3 ).

Three general hydrocarbon depth distributions of the headspace methane, ethane, and propane $\left(\mathrm{C}_{1}, \mathrm{C}_{2}, \mathrm{C}_{3}\right)$ were observed during Leg 139. The first consisted of low gas levels, represented at Sites 855 and 856 in Figures 2A and 2B (only 856 shown). The second distribution (Sites 857 and 858) has low $\mathrm{C}_{1}, \mathrm{C}_{2}, \mathrm{C}_{3}$ gas concentrations in the upper $160 \mathrm{mbsf}$, then a clear increase to higher levels at greater depths. The third distribution, seen at Holes $858 \mathrm{~B}, 858 \mathrm{D}$, and $858 \mathrm{~F}$, has high $\mathrm{C}_{1}$, $\mathrm{C}_{2}, \mathrm{C}_{3}$ in the near surface, i.e., uppermost 50 mbsf (Figs. 2A, 2B). The changes in the free gas $\mathrm{C}_{1}, \mathrm{C}_{2}, \mathrm{C}_{3}$ are concordant, i.e., the molecular $\mathrm{C}_{1} /\left(\mathrm{C}_{2}+\mathrm{C}_{3}\right)$ is relatively consistent with depth about a ratio of 100 (Fig. 2C). Hole $858 \mathrm{~A}$ is exceptional and shows $\mathrm{C}_{1} /\left(\mathrm{C}_{2}+\mathrm{C}_{3}\right)$ ratios up to $10^{4}$.

The carbon isotope ratios of the free-gas methane $\left(\delta^{13} \mathrm{C}_{\mathrm{CH}_{\mathrm{H}}}\right)$ are consistently lighter than $-51 \%$ (Table 3 ). As shown in the depth distribution in Figure 2D, this gas is more depleted in ${ }^{13} \mathrm{C}$ than the corresponding sorbed gas.

\section{DISCUSSION}

\section{Source Character of the Sorbed Hydrocarbons}

The two most notable aspects of the sorbed hydrocarbons from Leg 139 samples are (1) the presence of considerable amounts of ethane and propane, and (2) in many samples, the unusual occurrence of up to $7 \%$ unsaturated hydrocarbon gases (ethene and propene).

\section{Molecular Evidence of Thermogenic and Bacterial Hydrocarbons}

The elevated amounts of $\mathrm{C}_{2}$ and $\mathrm{C}_{3}$ hydrocarbons in the sorbed gases indicate the clear and dominant presence of thermogenic gas at all four sites of Leg 139. This interpretation, as discussed below, is supported by the several lines of evidence, including the $C_{1} /\left(C_{2}+C_{3}\right)$ ratio, the carbon isotope data of $\mathrm{C}_{1}, \mathrm{C}_{2}$ and $\mathrm{C}_{3}$ hydrocarbons, as well as the specific geologic setting of Middle Valley. There is also evidence in the sorbed gas data for a restricted bacterial gas presence. Furthermore, bacterial gas occurs in the free gas from Leg 139 sediments, as is discussed below. Therefore, the following discussion of the sorbed gases in these Juan de Fuca Ridge sediments will propose the interpretation that these hydrocarbon gases: (1) are predominantly of a thermogenic type, (2) are of a hydrothermal origin, and (3) in some cases, represent mixtures with minor amounts of bacterial methane.

It is well established that greater amounts of higher hydrocarbons, e.g., $\mathrm{C}_{2}$ and $\mathrm{C}_{3}$, in marine sediments can be attributed only to thermogenic formation (e.g., Hunt, 1979; Schoell, 1988; Whiticar, 1990). Bacterial activity, including methanogenesis, can generate only minor amounts of ethane and possibly propane (Oremland et al., 1988). The $\mathrm{C}_{2+}$ contribution, i.e., ethane and propane, to a bacterial gas rarely exceeds $1 \%$ of the methane formed and is typically $2-3$ orders of magnitude less. Trace amounts of $\mathrm{C}_{2}$ and $\mathrm{C}_{3}$ can also result from low temperature inorganic reactions with organic matter in sediments (e.g., Hunt et al., 1980), but again the amount of higher hydrocarbons found in Leg 139 sediments are considerably greater than expected by this inorganic transformation pathway. The $C_{1} /\left(C_{2}+C_{3}\right)$ ratio in all the samples except one (139-856A-13X-1, 137-142 cm), is less than 50 (Table 2, Fig. 1C), typical for natural gas generated thermogenically by the transformation of organic matter during catagenesis (e.g., Faber, 1987; Whiticar, 1990).

\section{Carbon Isotope Evidence of Thermogenic and Bacterial Hydrocarbons}

The methane carbon isotope ratios of the sorbed hydrocarbon gases provide significant interpretative information. The $\delta^{13} \mathrm{C}_{\mathrm{CH}_{4}}$ values between $-30 \%$ and $-45 \%$ fall in the range expected for thermogenic gases. The considerable scatter in the methane carbon isotope ratios reflects the diversity of thermal stresses operative in the Middle Valley. Although the majority of $\delta^{13} \mathrm{C}_{\mathrm{CH}_{4}}$ values substantiate the presence of thermogenic gases, the methane in some samples is depleted in ${ }^{13} \mathrm{C}$ (e.g., $\delta^{13} \mathrm{C}_{\mathrm{CH}_{4}}-54.9 \%$ in $857 \mathrm{C}-15 \mathrm{R}-3$ and $-50.1 \%$ in $858 \mathrm{~B}-$ $5 \mathrm{H}-1)$. These ${ }^{13} \mathrm{C}$-depleted methane values are isotopically too light for typical thermogenic sources, and would suggest a bacterial origin (Whiticar et al., 1986).

The combination of the molecular $\mathrm{C}_{1} /\left(\mathrm{C}_{2}+\mathrm{C}_{3}\right)$ ratios of the sorbed hydrocarbons, together with their corresponding methane isotope data $\left(\delta^{13} \mathrm{C}_{\mathrm{CH}_{4}}\right)$, illustrated in Figure 3 (after Bernard et al., 1978; Faber, 1987), support the interpretation that these natural gases are predominantly of thermogenic origin. The bacterial contribution would not be as readily apparent in Figure 3 without knowledge of the probability of bacterial gas in the free-gas fraction of the same sediments (see below). Other ODP examples of the juxtaposition of bacterial and ther- 


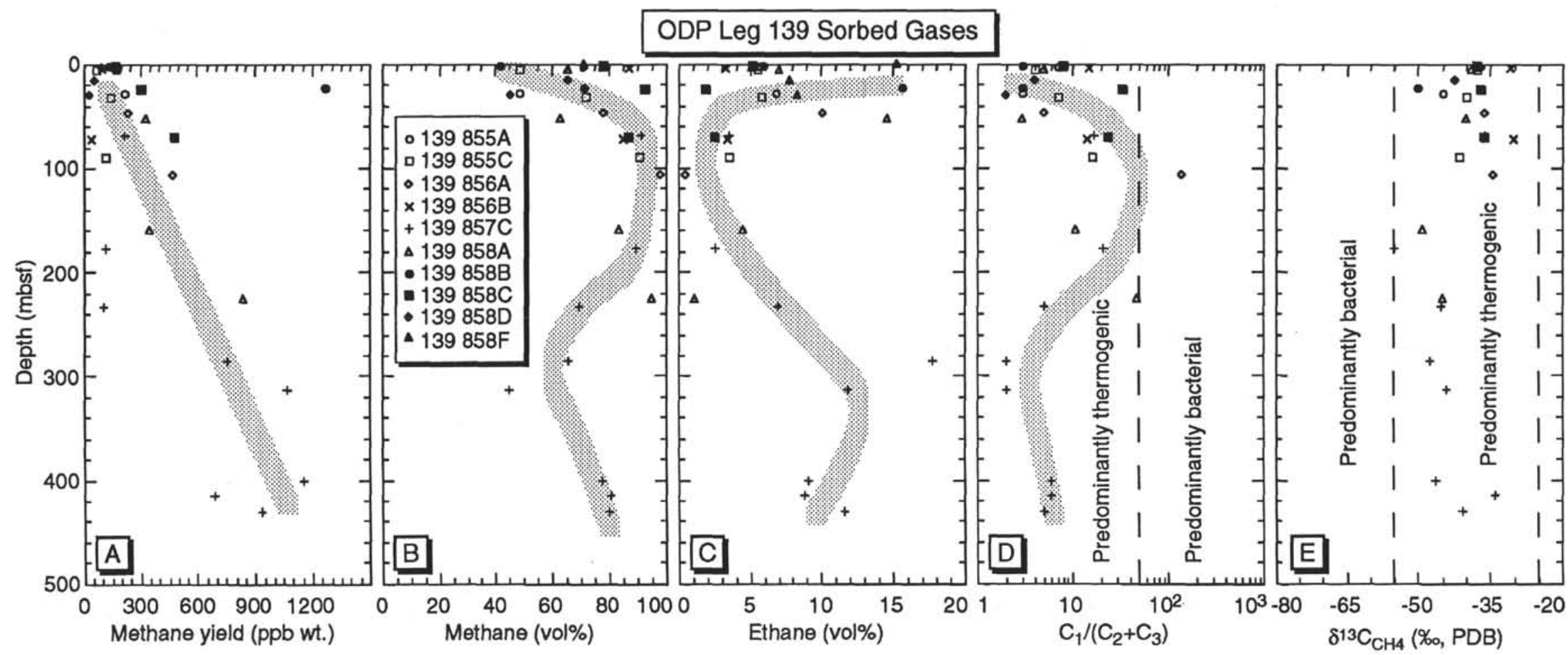

Figure 1. Depth distribution of sorbed gas measurements from Sites $855,856,857$, and 858 . Shading shows generalized depth distribution trends. 

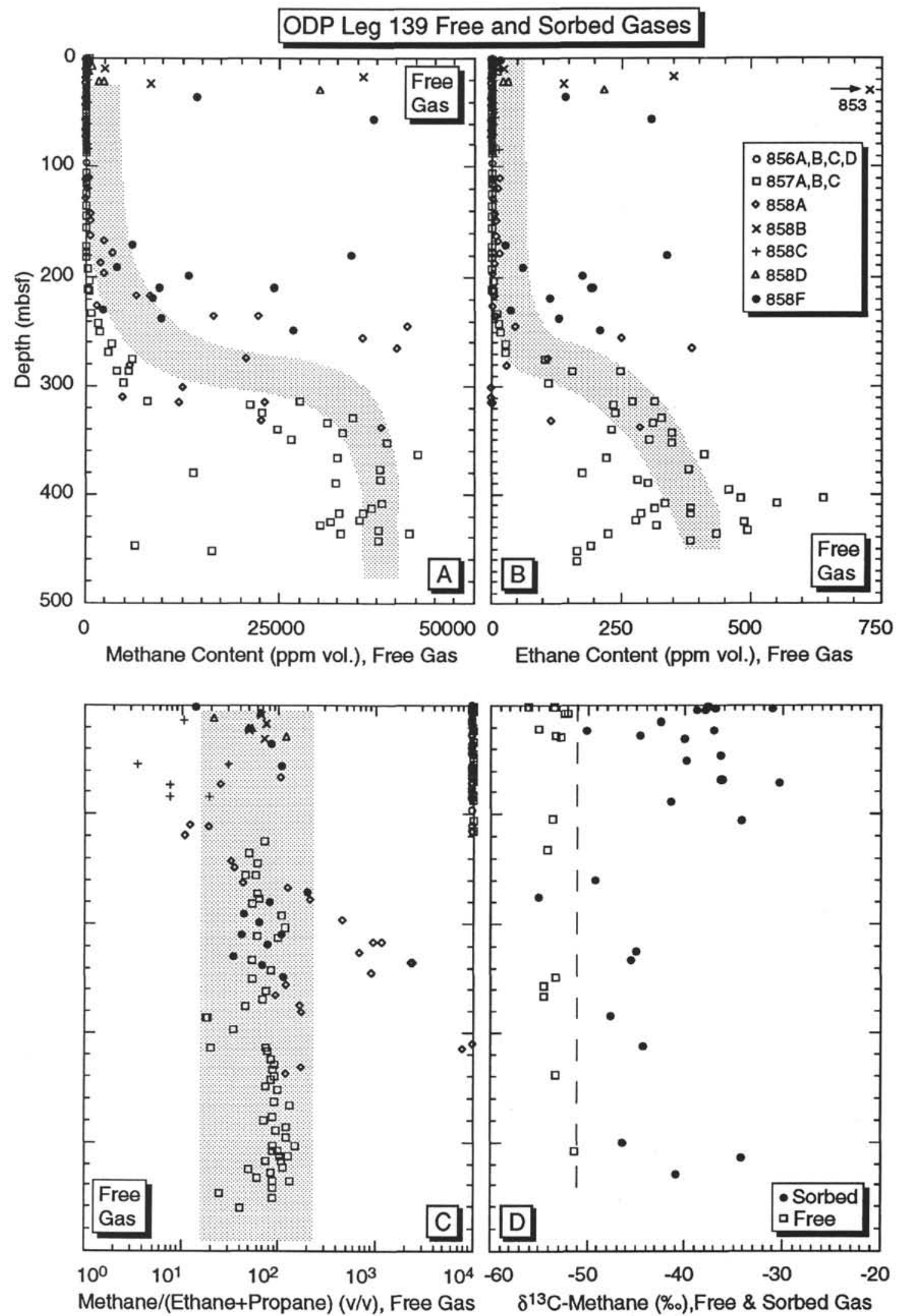

Figure 2. Depth distribution of free gas measurements from Sites 856, 857, and 858. A. Vol\% $\mathrm{CH}_{4} \cdot \mathbf{B} . \mathrm{Vol}_{6} \mathrm{C}_{2} \mathrm{H}_{6} \cdot$ C. $\mathrm{C}_{1} /\left(\mathrm{C}_{2}+\mathrm{C}_{3}\right)$. D. Free and sorbed $\delta^{13} \mathrm{C}_{\mathrm{CH}_{4}}$ ratios. 


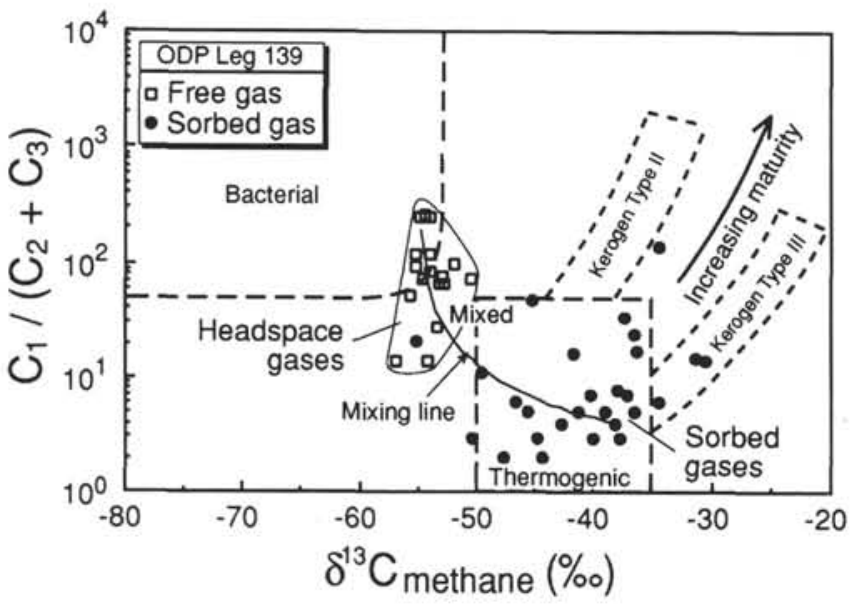

Figure 3. Combination of molecular $\mathrm{C}_{1} /\left(\mathrm{C}_{2}+\mathrm{C}_{3}\right)$ and isotope $\delta^{13} \mathrm{C}_{\mathrm{CH}_{4}}$ ratios of the sorbed and free hydrocarbon gases at Sites $855,856,857$, and 858 (after Bernard et al., 1978; Faber 1987; Whiticar, 1990). The mixing line according to Equations 8 and 9 is drawn for the $\delta^{13} \mathrm{C}_{\mathrm{CH}_{4}}-\mathrm{C}_{1} /\left(\mathrm{C}_{2}+\mathrm{C}_{3}\right)$ end-members pairs: $(-38 \%, 4)$ and $(-55 \%, 200)$. The source of the free gas is predominantly bacterial whereas the sorbed gas is largely thermogenic in origin.

mogenic hydrocarbon gases in the respective free and sorbed gases exist. At Leg 104, Vøring Plateau, Whiticar and Faber (1989) reported thermogenic hydrocarbons in the sediments as the basement was approached. Similarly, during Leg 112 at the Peru Margin the occurrence and migration of thermogenic hydrocarbons was characterized by the sorbed-gas fraction (Whiticar and Suess, 1990a).

The carbon isotope ratios of ethane and propane further strengthen the interpretation that the sorbed gases are predominantly thermogenic. Although a relatively wide range of $\delta^{13} \mathrm{C}_{\mathrm{C}_{2} \mathrm{H}_{6}}$ and $\delta^{13} \mathrm{C}_{\mathrm{C}_{3} \mathrm{H}_{8}}$ values was measured $(-18.7 \%$ o to $-26.1 \%$ and $-20.5 \%$ to $-25.1 \%$, respectively), the values are typical for thermogenic gases. Faber (1987) established an empirical relationship between $\delta^{13} \mathrm{C}_{\mathrm{C}_{2} \mathrm{H}_{6}}$ and $\delta^{13} \mathrm{C}_{\mathrm{C}_{3} \mathrm{H}_{3}}$ for thermogenic gases derived from source rocks of different maturities. The relationship:

$$
\delta^{13} \mathrm{C}_{\mathrm{C}_{3} \mathrm{H}_{8}}(\%)=0.93 \delta^{13} \mathrm{C}_{\mathrm{C}_{2} \mathrm{H}_{6}}(\%)+0.08,
$$

as shown in Figure 4, is typical for thermogenic gases from marine (Type II) kerogen. The Leg 139 sorbed gases, for which ethane and propane carbon isotope values are available, have a high degree of co-variance between $\delta^{13} \mathrm{C}_{\mathrm{C}_{2} \mathrm{H}_{6}}$ and $\delta^{13} \mathrm{C}_{\mathrm{C}_{3} \mathrm{H}_{8}}$, as shown in Figure 4. The $\delta^{13} \mathrm{C}_{\mathrm{C}_{2} \mathrm{H}_{6}}$ and $\delta^{13} \mathrm{C}_{\mathrm{C}_{3} \mathrm{H}_{8}}$ data pairs plot parallel and adjacent to the expected relationship for thermogenic gases. The variation in isotope ratios indicates that the sorbed gases have been generated from organic material which has been subjected to a range of thermal stress.

Due to the general predominance of methane generated by bacterial processes, a bacterial influence on the sorbed ethane was not observed in the $\delta^{13} \mathrm{C}_{\mathrm{C}_{2} \mathrm{H}_{8}}-\delta^{13} \mathrm{C}_{\mathrm{C}_{3} \mathrm{H}_{8}}$ cross plot (Fig. 4). In contrast, the $\delta^{13} \mathrm{C}_{\mathrm{CH}_{4}}-\delta^{13} \mathrm{C}_{\mathrm{C}_{2} \mathrm{H}_{6}}$ cross plot, illustrated in Figure 5, shows the strong influence of bacterial gas on the methane carbon isotope ratio. The strong departure of the sorbed gas $\delta^{13} \mathrm{C}_{\mathrm{CH}_{4}}-\delta^{13} \mathrm{C}_{\mathrm{C}_{2} \mathrm{H}_{6}}$ data pairs from the relationship expected for Type II kerogen defined by Faber (1987):

$$
\delta^{13} \mathrm{C}_{\mathrm{C}_{2} \mathrm{H}_{6}}(\%)=1.47 \delta^{13} \mathrm{C}_{\mathrm{CH}_{4}}(\%)+28.41 \text {, }
$$

indicates the admixture of bacterial gas to many of the samples. Changes in source type or maturity, or any secondary effect, such as bacterial methane oxidation (Whiticar and Faber, 1986) are not suitable alternative explanations for the departure in $\delta^{13} \mathrm{C}_{\mathrm{CH}_{4}}$, vis à vis $\delta^{13} \mathrm{C}_{\mathrm{C}_{\mathrm{H}} \mathrm{H}}$ seen in Figure 5. These effects would result in an isotope shift opposite to that observed and opposite to the isotope offset expected for the admixture of bacterial gas.

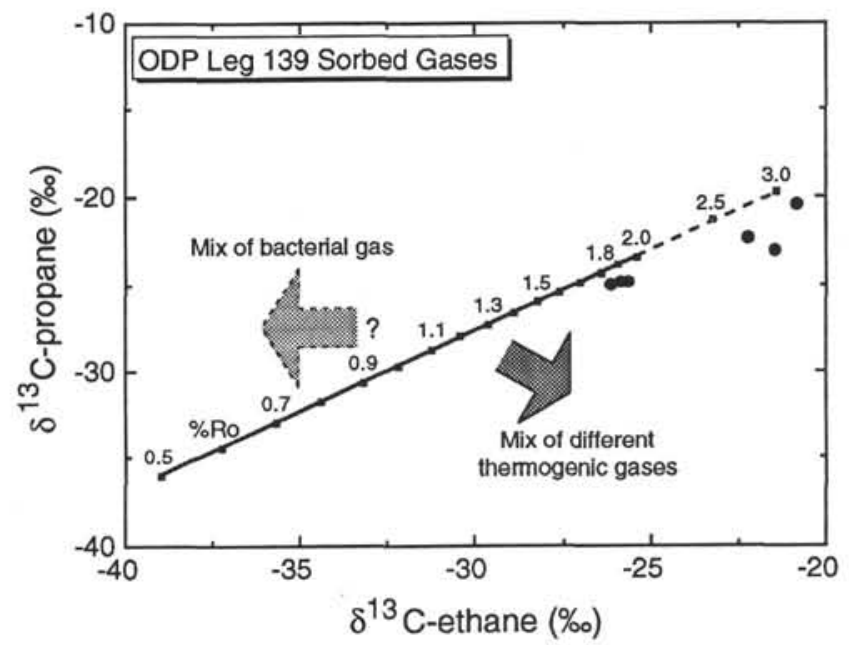

Figure 4. Cross plot of ethane and propane stable carbon isotope ratio pairs for the sorbed gases. The reference line, drawn according to Equation 2, and the corresponding maturation levels are for typical for Type II kerogen (after Faber 1987; Whiticar, 1990). These data pairs show no effects of bacterial gas or oxidation (their possible trajectories are shown by the broad arrows).

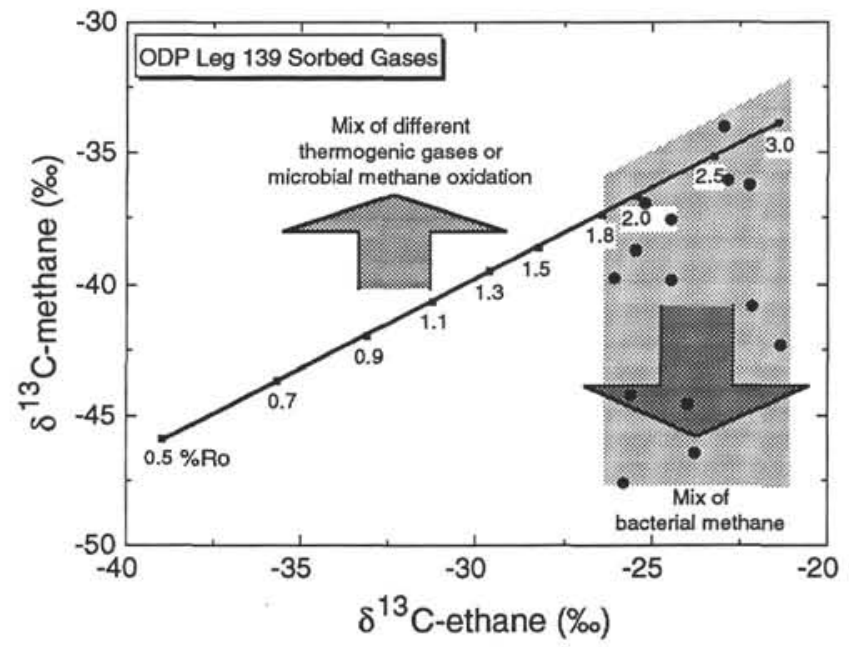

Figure 5. Cross plot of ethane and methane stable carbon isotope ratio pairs for the sorbed gases. The reference line, drawn according to Equation 3, and the corresponding maturation levels are for typical for Type II kerogen (after Faber 1987; Whiticar, 1990). In contrast to Figure 3, the departure of several methane-ethane data pairs shows the variable admixture of bacterial gas (methane) with thermogenic gas.

\section{Estimation of Thermal Maturity}

An empirical relationship between the carbon isotope ratios of methane, ethane, or propane in a natural gas and the vitrinite reflectance of the responsible source was established initially by Stahl and Koch (1974) and later revised by Whiticar et al. (1984) and Faber (1987). For kerogen Types I/II the calibrated relationships between the carbon isotope ratios and vitrinite reflectance (\% Ro) are:

$$
\begin{aligned}
& \delta^{13} \mathrm{C}_{\mathrm{CH}_{4}}\left(\% o=15.4 \log _{(10)} \% \text { Ro }-41.3,\right. \\
& \delta^{13} \mathrm{C}_{\mathrm{C}_{2} \mathrm{H}_{6}}(\% o)=22.6 \log _{(10)} \% \text { Ro }-32.2, \\
& \delta^{13} \mathrm{C}_{\mathrm{C}_{3} \mathrm{H}_{8}}(\% o)=20.9 \log _{(10)} \% \text { Ro }-29.7 .
\end{aligned}
$$

Although it is uncertain if these specific relationships are transferable to the organic source situation encountered during Leg 139, 


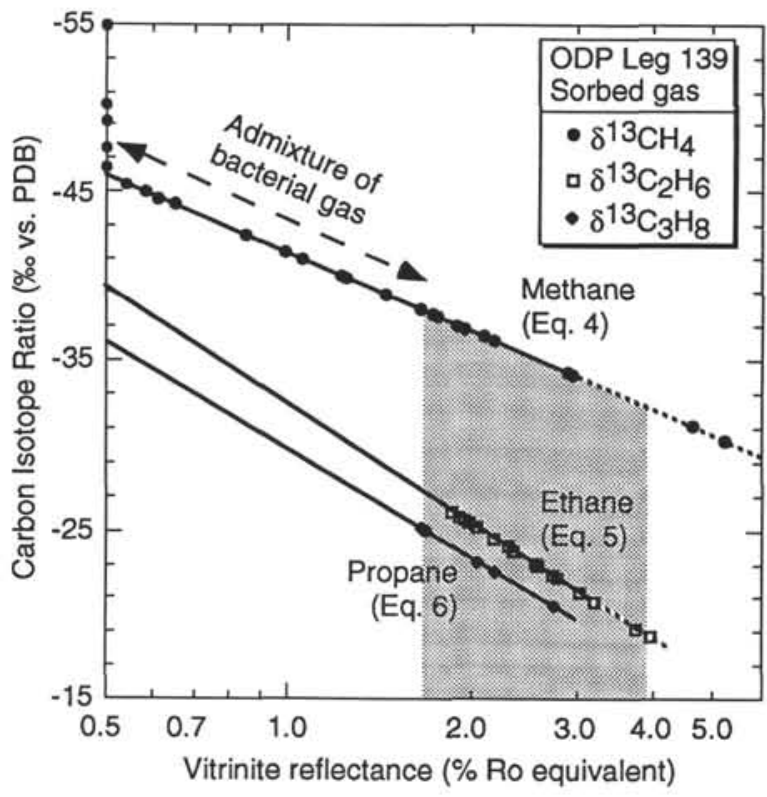

Figure 6. Methane, ethane, and propane carbon isotope ratios vs. equivalent maturity of source organic matter responsible for generating the thermogenic hydrocarbons in the sorbed gases. Note: \% Ro referred to here is a vitrinite reflectance equivalent, not a measured value, but it is calculated and plotted from the $\mathrm{C}$-isotope data according to Equations 4,5 , and 6 . The strong departure of the methane isotope data relative to ethane and propane indicates the admixture of bacterial methane gas. Maturities estimated from ethane and propane range between $1.8 \%$ and $4.0 \%$ Ro (vitrinite reflectance equivalent).

Figure 6 illustrates the possible range in maturities estimated from the light hydrocarbons for the responsible organic matter. Using Equations 5 and 6 to calculate and plot the maturity level $(\%$ Ro $=$ vitrinite reflectance equivalence) in Figure 6, the ethane and propane isotope data indicate a maturity range between $1.8 \%$ Ro and $4.0 \%$ Ro. This considerable range in estimated maturity reflects the local and regional heterogeneity of heat and flow regimes in the subsurface at Middle Valley. Temperatures at Sites 855 and 856 were relatively low (max. ca. $26^{\circ} \mathrm{C}$ and $70^{\circ} \mathrm{C}$, respectively), with thermal gradients estimated to be $0.328^{\circ} \mathrm{C} / \mathrm{m}$ and $0.5^{\circ} \mathrm{C} / \mathrm{m}$ (Table 1). In contrast, temperatures of up to $230^{\circ} \mathrm{C}$ and $260^{\circ} \mathrm{C}$ and thermal gradients of up to $10^{\circ} \mathrm{C} / \mathrm{m}$ were encountered at Sites 857 and 858, respectively (Table 1). Figure 7 shows the temperature depth gradients encountered during Leg 139 drilling (after data from Davis, Mottl, Fisher, et al., 1992). Sites 855 and 856 are much cooler and reside in the immature, diagenetic zone $\left(<50^{\circ} \mathrm{C}\right)$, whereas Sites 857 and 858 are hotter and extend into the mature, catagenic zone (ca. $\left.150^{\circ} \mathrm{C}\right)$ and in some instances into the overmature, metagenic zone $\left(>150^{\circ} \mathrm{C}\right)$.

Similar maturities are calculated using Equation 4 for methane isotope data corresponding to some sorbed-gas samples, but the majority of the methane isotope data for the sorbed gas are depleted in ${ }^{13} \mathrm{C}$ relative to the value expected for the level of maturity expected based on the ethane and propane isotope data. This isotope-maturity discrepancy suggests the admixture of isotopically lighter methane to the thermogenic signature, i.e., the addition of methane-rich bacterial gas.

\section{Evidence of Hydrothermal Activity}

Considering the location of the drill holes and the geochemical conditions encountered at the Juan de Fuca Ridge, including temperature (e.g., Fig. 7) and organic matter (see Davis, Mottl, Fisher, et al., 1992), it is expected that there should be hydrothermal generation of hydrocarbons. This is consistent with occurrences of hydrothermal hydrocarbons reported for other submarine hydrothermal activity, e.g., Welhan and Craig (1979), Welhan and Lupton (1987), Whiticar et al. (1985),

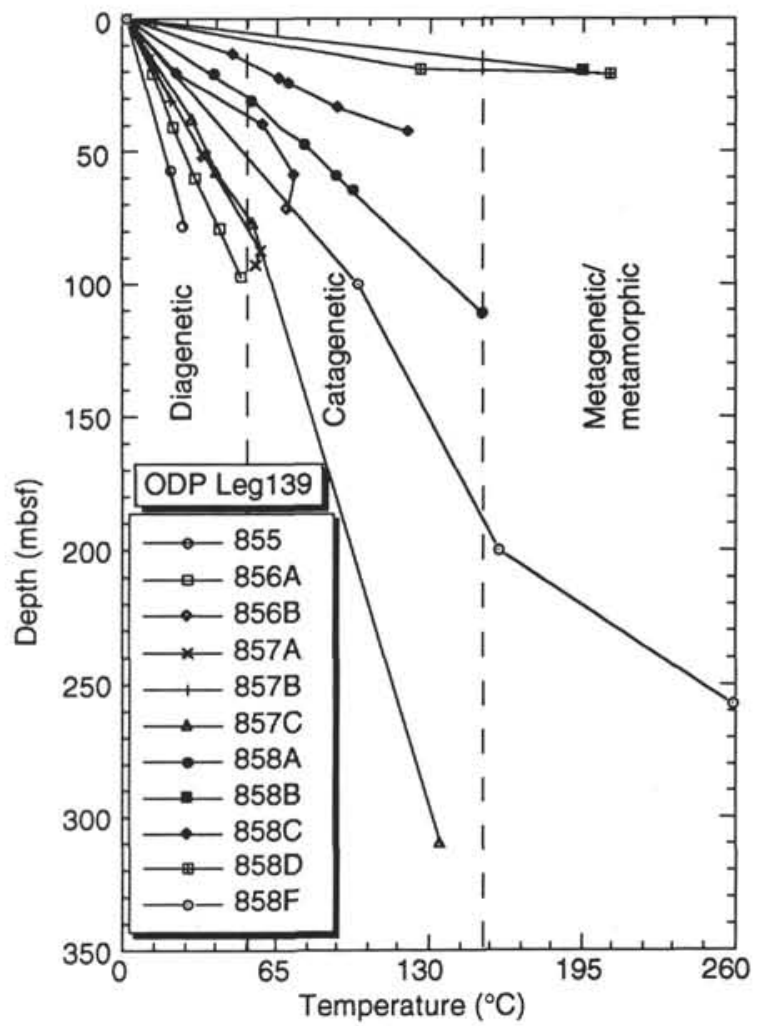

Figure 7. Temperature depth gradients observed (after Davis, Mottl, Fisher, et al., 1992). Sites 855 and 856 are $<50^{\circ} \mathrm{C}$ and reside in the immature, diagenetic zone, whereas Sites 857 and 858 extend clearly into the mature, catagenic zone (ca. $150^{\circ} \mathrm{C}$ ) and in some instances into the overmature, metagenic zone $\left(>150^{\circ} \mathrm{C}\right)$.

Simoneit et al. (1988), Whiticar and Suess (1990b), and Gerling (1985). At several of these sites it was the presence of abnormal amounts of the olefins ethene and propene in conjunction with the higher hydrocarbons that signaled the hydrothermal character of the gases in the sediments and water columns. Similarly, significant amounts of both ethene and propene were recorded for several sorbed-gas samples (up to $7 \mathrm{vol} \%$ and $4 \mathrm{vol} \%$ respectively, Table 2 ). There is no consistent depth distribution of the olefins, but in the cases of samples with elevated amounts of ethene and propene, the corresponding saturated hydrocarbons are also higher (Fig. 8). Olefins are not stable over geologic time and are a reliable indicator for recent generation. In addition, higher amounts of ethene and propene in Leg 139 sediments are consistent with the results from other hydrothermal and geothermal settings, e.g., Whiticar and Suess (1990b) and DesMarais et al. (1981). Drilling into resistant lithologies can also artificially generate higher hydrocarbons (bit metamorphism), including olefins (Faber et al., 1987; Faber and Whiticar, 1989), but this is not considered likely in the sorbed-gas samples analyzed. Bit metamorphic gases generally have anomalous isotope ratios, different from those observed here.

\section{Source Character of the Free Hydrocarbons}

The headspace and EVG free gases in sediments from Leg 139 are discussed in considerable detail in Davis, Mottl, Fisher, et al. (1992). There appears to be considerable difference between the free and sorbed gases. Whereas the sorbed hydrocarbon gases demonstrate a clear hydrothermal-thermogenic influence, the free gases are somewhat more ambiguous. In both the headspace and EVG gases, there are considerable amounts of higher hydrocarbons. This points to a thermogenic source. In addition, several headspace samples possess ethylene in the presence of higher hydrocarbons (Davis, Mottl, Fisher, et al., 


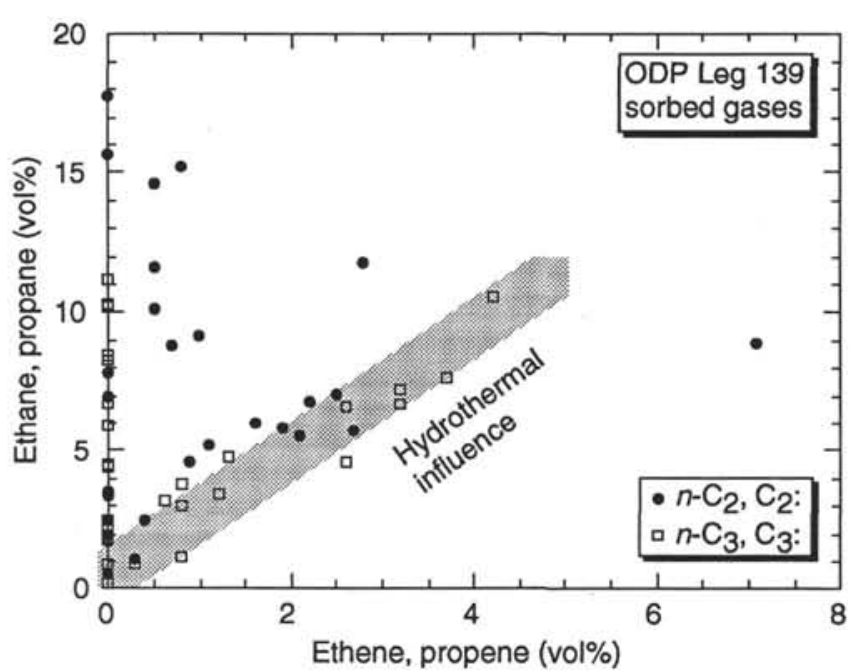

Figure 8. Cross plot of the $\mathrm{C}_{2}, \mathrm{C}_{3}$ n-alkanes (ethane, propane) vs. unsaturated $\mathrm{C}_{2}, \mathrm{C}_{3} \mathrm{n}$-alkenes (ethene, propene). The high proportions of olefins in the sorbed and free gases is typical of hydrocarbon generation at hydrothermal settings.

1992), analogous to the hydrothermal evidence presented for the sorbed gases. The difference between the sorbed and free gases is that the latter strongly indicate the influence of bacterial gas. Figure 3 illustrates this influence. Interestingly, the sorbed gases that show bacterial gas admixture fall along a mixing line leading to the free gases. It is not likely that secondary effects such as migration or microbial oxidation are responsible for the isotopically lighter free gas. Both of these processes would typically cause a ${ }^{13} \mathrm{C}$ enrichment in the residual methane, which is not observed in these samples. The occurrence and distribution of bacterial methane is consistent with the geochemical situation found at Leg 139 sites. The free-gas levels observed at Sites 855 or 856 (Fig. 2 and Davis, Mottl, Fisher, et al., 1992) are low. In both of these sediments the dissolved sulfate concentrations are high (Fig. 9, Table 1, and Davis, Mottl, Fisher, et al., 1992), precluding methanogenesis (e.g., Claypool and Kaplan, 1974; Whiticar et al., 1986). At Holes 857C and 857D, dissolved sulfate is close to exhaustion around $200 \mathrm{mbsf}$, corresponding to the depth of methane appearance in the free gas (Fig. 2). Hole 858A also shows a clear increase in methane content below $200 \mathrm{mbsf}$, where the sulfate drops to low levels. Dissolved sulfate drops quickly to $0 \mathrm{mM}$ by $26 \mathrm{mbsf}$ at Hole $858 \mathrm{~B}$, corresponding to a rapid rise in methane in the free-gas phase. This relationship of low methane in the sulfate zone is also expressed at Holes $858 \mathrm{C}, 858 \mathrm{D}$, and $858 \mathrm{~F}$. It is interesting to note that the dissolved sulfate concentrations in several holes at Sites 857 and 858 do not decrease to zero with depth and remain around $5 \mathrm{mM}$ (Fig. 9). Considering the steep decrease in dissolved sulfate down to $5 \mathrm{mM}$ by 200 mbsf (e.g., in Holes $857 \mathrm{C}$ or $858 \mathrm{~A}$ and $858 \mathrm{~F}$ ), it would be expected that sufficient nonrefractory organic matter is available to sulfate-reducing bacteria to completely exhaust the available sulfate (buried and downward diffusing $\mathrm{SO}_{4}=$ ). The fact that dissolved sulfate is present in significant amounts at depth suggests an atypical, nonsteady-state diagenetic situation. Furthermore, as shown in Figure 10, Sites 855 and 856 show the usual $\mathrm{C}: \mathrm{S}(\sim 2: 1.3)$ stoichiometry relating the bacterial uptake of dissolved sulfate and release of remineralized bicarbonate. In contrast, the samples from Sites 857 and 858 do not have this expected stoichiometry. Certainly the elevated temperatures encountered at Sites 857 and 858 (Fig. 7) $\left(>150^{\circ} \mathrm{C}\right.$ ), exceed the range normally considered necessary for bacterial activity, which would shut down in-situ sulfate reduction or methanogenesis.

\section{Evidence for Fluid Flow at the Juan de Fuca Ridge}

No clear indication of migration exists in most of the gases analyzed, although it cannot be ruled out. Considering the extreme range

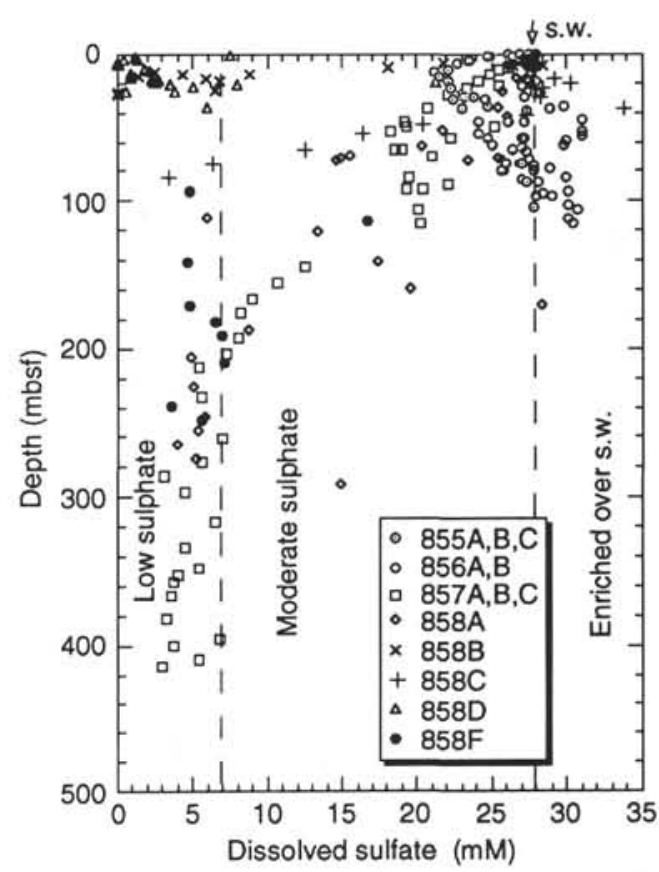

Figure 9. Depth distribution of dissolved sulfate.

in thermal regimes encountered during Leg 139, an autochthonous origin for these gases is also reasonable. The yield of methane in the sorbed gases was low at Sites 855 and 856 , as was found for the corresponding free gas. There is no gas evidence of flow at these sites. At Sites 857 and 858 , the dissolved sulfate determines the vertical distribution of methane, in particular the formation of bacterial gas. The high temperatures measured in the sediments (Fig. 7) could account for the thermogenic hydrocarbons present, but there is no reason to invoke any major gas migration for the gases in the deeper sections. A possible indication of vertical gas movement is the relatively homogeneous $\mathrm{C}_{1} /\left(\mathrm{C}_{2}+\mathrm{C}_{3}\right)$ ratio and methane carbon isotope ratios throughout the sediment column at Site 857 and at the deeper holes at Site 858. In these cases, limited, short-distance advection and diffusion $(\sim 100 \mathrm{~m})$ may be responsible. The interstitial fluids (e.g., dissolved sulfate and alkalinity) also suggest some fluid movement. The persistence of dissolved sulfate around $5 \mathrm{mM}$ at depth in Holes $857 \mathrm{~A}, 857 \mathrm{~B}$, and $857 \mathrm{C}$ (Fig. 9), despite bacterial sulfate reduction, requires continual replenishment of sulfate. Some sulfate will diffuse downward from the surface sediments along the concentration gradient, but either upward or lateral migration of sulfate-bearing fluids is also required to maintain the profile observed.

\section{Proportion of Bacterial Gas}

If the isotope signature of the end-members of a binary mixture are known, then it is possible, for a discrete sample, to calculate the relative proportions of each present in the mixture, according to a simple mass balance:

$$
\delta_{\mathrm{m}}=\mathrm{m}_{\mathrm{a}} \delta_{\mathrm{a}}+\left(1-\mathrm{m}_{\mathrm{a}}\right) \delta_{\mathrm{b}},
$$

where $\delta_{\mathrm{m}}$ is the isotope ratio measured in the sample (e.g., $\delta^{13} \mathrm{C}_{\mathrm{CH}_{4}}$ ), $\delta_{\mathrm{a}}$ and $\delta_{\mathrm{b}}$ are the isotope signatures of the end-members "a" and " $\mathrm{b}$," and $\mathrm{m}$ is the fraction of end-member " $\mathrm{a}$ " present. If the end-members are either not consistent or not known, then the simple calculation using Equation 7 cannot be made and determination of mixing becomes more difficult. A series of samples are then required to define the mixing line. Assuming the gases collected during Leg 139 are a mixture of no more than 2 gas types, thermogenic $\left(\delta^{13} \mathrm{C}_{\mathrm{CH}_{4}}=-38 \%\right)$ 


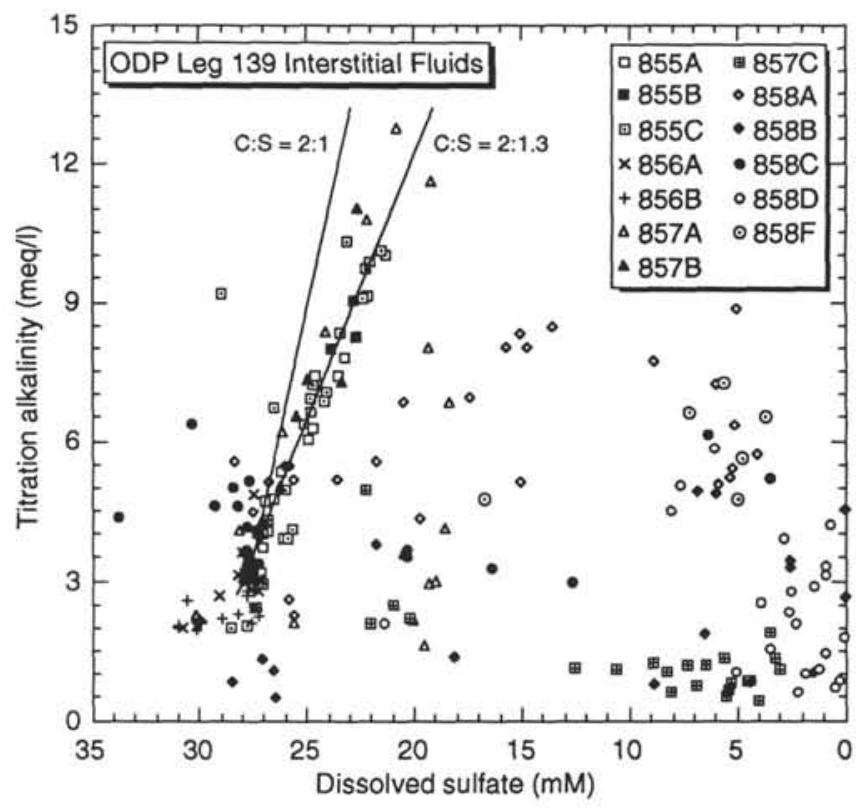

Figure 10. Relationship of titration alkalinity to dissolved sulfate (after Davis, Mottl, Fisher, et al., 1992). Typical C:S, i.e., $\Sigma \mathrm{CO}_{2}: \mathrm{SO}_{4}=$ stoichiometric lines expected by diagenesis are shown in the figure. Sites 856 and 856 generally obey the C:S remineralization ratios, but Sites 857 and 858 depart strongly from the expected C:S ratios.

and bacterial $\left(\delta^{13} \mathrm{C}_{\mathrm{CH}_{4}}=-55 \%\right.$ ), then based on Equation 7 the free gases may contain up to $30 \%$ thermogenic gas, whereas some of the sorbed gases are mostly bacterial.

Some of the difficulty and uncertainty in estimating the isotope end-members for a two-component mixture can be overcome by combining the compositional $\mathrm{C}_{1} /\left(\mathrm{C}_{2}+\mathrm{C}_{3}\right)$ ratio with the methane carbon isotope ratio from a sample series. The 2-D mixing line calculated from the isotope and molecular ratios can be described by (Whiticar and Faber, 1989):

$$
\begin{gathered}
\delta_{m}=\left(\mathrm{mB}_{\mathrm{a}} /\left(1+\mathrm{B}_{\mathrm{a}}\right) \delta_{\mathrm{a}}+(1-\mathrm{m}) \mathrm{B}_{\mathrm{b}} /\left(1+\mathrm{B}_{\mathrm{b}}\right) \delta_{\mathrm{b}}\right) / \mathrm{F}_{\mathrm{m}}, \\
\mathrm{B}_{\mathrm{m}}=\mathrm{F}_{\mathrm{m}} /\left(1-\mathrm{F}_{\mathrm{m}}\right),
\end{gathered}
$$

and

$$
\mathrm{F}_{\mathrm{m}}=\mathrm{mB}_{\mathrm{a}} /\left(1+\mathrm{B}_{\mathrm{a}}\right)+(1-\mathrm{m}) \mathrm{B}_{\mathrm{b}} /\left(1+\mathrm{B}_{\mathrm{b}}\right),
$$

where $B$ is the $C_{1} /\left(C_{2}+C_{3}\right)$ ratio of the end-members a and $b$, and $m$ is that of the mixed pair. A reasonable fit to the sorbed- and free-gas data in Figure 3 is drawn according to Equations 8, 9, and 10, calculated from the $\delta^{13} \mathrm{C}_{\mathrm{CH}_{1}}-\mathrm{C}_{1} /\left(\mathrm{C}_{2}+\mathrm{C}_{3}\right)$ end-member data pairs $(-55 \%$, $200)$ and $(-38 \%, 4)$. From this best-fit choice of end-members, thermogenic gas makes up $15 \%-20 \%$ of the free gas, whereas the sorbed gases demonstrate a much larger range of bacterial contributions $(0 \%$ to $\sim 85 \%$ ).

\section{CONCLUSIONS}

The hydrocarbon gases encountered during Leg 139 are of both thermogenic and bacterial origin. The thermogenic hydrocarbons at Sites 857 and 858 are probably autochthonous, formed as the result of local hydrothermal alteration of organic matter (natural hydrous pyrolysis). Variations in the thermal history of the two sites leads to considerable range in the maturation of the organic matter, as reflected in the sorbed- and free-gas molecular and carbon isotope ratios.

\section{ACKNOWLEDGMENTS}

This paper typifies the international scientific cooperation facilitated by the Ocean Drilling Program. Sample collection and shipboard gas chromatography were by the shipboard geochemists (BRTS and JKW, in USA), the sorbed-gas analyses by the BGR in Hannover (EF and MJW, in FRG) and the free-gas analyses at SEOS in Victoria by T. Cederberg. The first author's UVic activities are supported by NSERC Strategic Research and Operating Grants STR0118459 and OGP0105389.

\section{REFERENCES ${ }^{*}$}

Bernard, B.B., Brooks, J.M., and Sackett, W.M., 1978. Light hydrocarbons in recent Texas continental shelf and slope sediments. J. Geophys. Res., 83:4053-4061.

Claypool, G.E., and Kaplan, I.R., 1974. The origin and distribution of methane in marine sediments. In Kaplan, I.R. (Ed.), Natural Gases in Marine Sediments: New York (Plenum), 99-139.

Davis, E.E., Mottl, M.J., Fisher, A.T., et al., 1992. Proc. ODP, Init. Repts., 139: College Station, TX (Ocean Drilling Program).

DesMarais, D.J., Donchin, J.H., Nehring, N.L., and Truesdell, A.H., 1981. Molecular carbon isotopic evidence for the origin of geothermal hydrocarbons. Nature, 292:826-828.

Faber, E., 1987. Zur Isotopengeochemie gasförmiger Kohlenwasserstoffe. Erdoel, Erdgas, Kohle, 103:210-218.

Faber, E., Gerling, P., and Dumke, I., 1987. Gaseous hydrocarbons of unknown origin found while drilling. Org. Geochem., 13:875-879.

Faber, E., and Stahl, W., 1984. Geochemical surface exploration for hydrocarbons in North Sea. AAPG Bull., 68:363-386.

Faber, E., and Whiticar, M.J., 1989. C- und -Isotope in leichtfluchtige Kohlenwasserstoffen der KTB. KTB Rep.

Gerling, P., 1985. Isotopengeochemische Oberflächenprospektion Onshore. BGR Intern. Rep., 98576.

Hunt, J.M., 1979. Petroleum Geochemistry and Geology: San Francisco (W.H. Freeman).

Hunt, J.M., Huc, A.Y., and Whelan, J.K., 1980. Generation of light hydrocarbons in sedimentary rocks. Nature, 288:688-690.

Oremland, R.S., Whiticar, M.J., Strohmaier, F.E., and Kiene, R.P., 1988. Bacterial ethane formation from reduced, ethylated sulfur compounds in anoxic sediments. Geochim. Cosmochim. Acta, 52:1895-1904.

Schoell, M. (Ed.), 1988. Origins of Methane in the Earth. Chem. Geol., 71.

Simoneit, B.R.T., Kawka, O.E., and Brault, M., 1988. Origin of gases and condensates in the Guaymas Basin hydrothermal system (Gulf of California). Chem. Geol., 71:169-182.

Stahl. W., and Koch, J., 1974. ${ }^{13} \mathrm{C} /{ }^{12} \mathrm{C}$-Verhälltnis nordeutscher ErdgaseReifemerkmal ihrer Muttersubstanzen. Erdoel Kohle, Erdgas, Petrochem., 27:10.

Welhan, J.A., and Craig, H., 1979. Methane and hydrogen in the East Rise hydrothermal fluids. Geophys. Res. Lett., 6:829-832.

Welhan, J.A., and Lupton, J.E., 1987. Light hydrocarbon gases in Guaymas Basin hydrothermal fluids: thermogenic versus abiogenic origin. AAPG Bull. 71:215-223.

Whiticar, M.J., 1990. A geochemical perspective of natural gas and atmospheric methane. In Durand, B., and Behar, F. (Eds.), Advances in Organic Geochemistry 1989. Org. Geochem., 16:531-547.

Whiticar, M.J., and Cederberg, T., in press. Stable carbon isotope determinations of hydrocarbon gases at the picomole level by GC-C-IRMS. in preparation for Anal. Chem.

Whiticar, M.J., and Faber, E., 1986. Methane oxidation in sediment and water column environments-isotope evidence. Org. Geochem., 10:759-768. , 1989. Molecular and stable isotope composition of headspace and total hydrocarbon gases at ODP Leg 104, Sites 642, 643, and 644, Vøring Plateau, Norwegian Sea. In Eldholm, O., Thiede, J., Taylor, E., et al., Proc. ODP, Sci. Results, 104: College Station, TX (Ocean Drilling Program), 327-334.

\footnotetext{
- Abbreviations for names of organizations and publications in ODP reference lists follow the style given in Chemical Abstracts Service Source Index (published by American Chemical Society).
} 
Whiticar, M.J., Faber, E., and Schoell, M., 1984. Carbon and hydrogen isotopes of $\mathrm{C}_{1}-\mathrm{C}_{5}$ hydrocarbons in natural gases. AAPG Research Conf. on Natural Gases, San Antonio, TX.

, 1986. Biogenic methane formation in marine and freshwater environments: $\mathrm{CO}_{2}$ reduction vs. acetate fermentation-isotope evidence. Geochim. Cosmochim. Acta, 50:693-709.

Whiticar, M.J., and Suess, E., 1990a. Characterization of sorbed volatile hydrocarbons from the Peru margin, Leg 112, Sites 679, 680/681, 682, 684, and 686/687. In Suess, E., von Huene, R., et al., Proc. ODP, Sci. Results, 112: College Station, TX (Ocean Drilling Program), 527-538. 1990b. Hydrothermal hydrocarbon gases in the sediments of the King George Basin, Bransfield Strait, Antarctica. Appl. Geochem., 5:135147.

Whiticar, M.J., Suess, E., and Wehner, H., 1985. Thermogenic hydrocarbons in surface sediments of the Bransfield Strait, Antarctic Peninsula. Nature, 314:87-90.

Date of initial receipt: 29 March 1993

Date of acceptance: 29 September 1993

Ms 139SR-241 